\title{
Preservation media, durations and cell concentrations of short-term storage affect key features of human adipose- derived mesenchymal stem cells for therapeutic application
}

\author{
Fengli Zhang ${ }^{1}$, Huaijuan Ren ${ }^{1}$, Xiaohu Shao ${ }^{1}$, Chao Zhuang ${ }^{1}$, Yantian Chen ${ }^{c}$ \\ ${ }^{1}$ Cell Culture and Bioprocess Engineering Lab, School of Pharmacy, Shanghai Jiao Tong University, Shanghai, China \\ 2 China Stem Cell Therapy Co., Limited, Shanghai, Shanghai, China \\ Corresponding Authors: Yantian Chen, Nianmin Qi \\ Email address: ytchen@sjtu.edu.cn, biotech@sjtu.edu.cn
}

Nianmin Qi Corresp. 1,2

Background. Adipose-derived mesenchymal stem cells (ADSCs) have shown great potential in the treatment of various diseases. However, the optimum short-term storage condition of $A D S C s$ in $2 \sim 8^{\circ} \mathrm{C}$ is rarely reported. This study aimed at optimizing a shortterm storage condition to ensure the viability and function of ADSCs before transplantation. Methods. Preservation media and durations of storage were evaluated by cell viability, apoptosis, adhesion ability and colony-forming unit (CFU) capacity of ADSCs. The abilities of cell proliferation and differentiation were used to optimize cell concentrations. Optimized preservation condition was evaluated by cell surface markers, cell cycle and immunosuppressive capacity. Results. 5\% human serum albumin in multiple electrolytes (ME+HSA) was the optimized medium with high cell viability, low cluster rate, good adhesion ability and high CFU capacity of ADSCs. Duration of storage should be limited to $24 \mathrm{~h}$ to ensure the quality of ADSCs before transplantation. $5 \times 10^{6}$ cells/ml was the most suitable cell concentration with low late stage apoptosis, rapid proliferation and good osteogenic and adipogenic differentiation ability. This selected condition did not change surface markers, cell cycle, indoleamine 2, 3-dioxygenase 1 (IDO1) gene expression and kynurenine (Kyn) concentration significantly. Discussion. In this study, ME+HSA was found to be the best medium, most likely due to the supplement of HSA which could protect cells, the physiological pH (7.4) of ME and sodium gluconate ingredient in ME which could provide energy for cells. Duration should be limited to $24 \mathrm{~h}$ because of reduced nutrient supply and increased waste and lactic acid accumulation during prolonged storage. $5 \times 10^{6} \mathrm{cells} / \mathrm{ml}$ is the proper cell concentration keep the proliferation of cells and limit lactic acid accumulation. Surface markers, cell cycle and immunosuppressive capacity did not change significantly after storage using the optimized condition, which confirmed our results that this optimized short-term storage condition of MSCs has a great potential for the application of cell therapy. 
1 Preservation media, durations and cell concentrations of short-term storage affect key features of human adiposederived mesenchymal stem cells for therapeutic application

4 Fengli Zhang ${ }^{1}$, Huaijuan Ren ${ }^{1}$, Xiaohu Shao ${ }^{1}$, Chao Zhuang ${ }^{1}$, Yantian Chen ${ }^{1, *}$, Nianmin $\mathrm{Qi}^{1,2, *}$

$5{ }^{1}$ Cell Culture and Bioprocess Engineering Lab, School of Pharmacy, Shanghai Jiao Tong University,

6 Shanghai, China

$7 \quad{ }^{2}$ China Stem Cell Therapy Co., Limited, Shanghai, China

8

9 Corresponding Authors:

10 Yantian Chen $^{1}$

11800 Dongchuan Road, Minhang District, Shanghai, 200240, China

12 Email Address: ytchen@sjtu.edu.cn

13 Nianmin $\mathrm{Qj}^{1,2}$

14800 Dongchuan Road, Minhang District, Shanghai, 200240, China

15 Email Address: biotech@sjtu.edu.cn 
18 Abstract

19

Background. Adipose-derived mesenchymal stem cells (ADSCs) have shown great potential in the treatment of various diseases. However, the optimum short-term storage condition of ADSCs in $2 \sim 8^{\circ} \mathrm{C}$ is rarely reported. This study aimed at optimizing a short-term storage condition to ensure the viability and function of ADSCs before transplantation.

Methods. Preservation media and durations of storage were evaluated by cell viability, apoptosis, adhesion ability and colony-forming unit (CFU) capacity of ADSCs. The abilities of cell proliferation and differentiation were used to optimize cell concentrations. Optimized preservation condition was evaluated by cell surface markers, cell cycle and immunosuppressive capacity.

Results. 5\% human serum albumin in multiple electrolytes (ME+HSA) was the optimized medium with high cell viability, low cluster rate, good adhesion ability and high CFU capacity of ADSCs. Duration of storage should be limited to $24 \mathrm{~h}$ to ensure the quality of ADSCs before transplantation. $5 \times 10^{6} \mathrm{cell} \mathrm{s} / \mathrm{ml}$ was the most suitable cell concentration with low late stage apoptosis, rapid proliferation and good osteogenic and adipogenic differentiation ability. This selected condition did not change surface markers, cell cycle, indoleamine 2, 3-dioxygenase 1 (IDO1) gene expression and kynurenine (Kyn) concentration significantly. 
supplement of HSA which could protect cells, the physiological pH (7.4) of ME and sodium gluconate ingredient in ME which could provide energy for cells. Duration should be limited to $24 \mathrm{~h}$ because of reduced nutrient supply and increased waste and lactic acid accumulation during prolonged storage. $5 \times 10^{6} \mathrm{cells} / \mathrm{ml}$ is the proper cell concentration keep the proliferation of cells and limit lactic acid accumulation. Surface markers, cell cycle and immunosuppressive capacity did not change significantly after storage using the optimized condition, which confirmed our results that this optimized short-term storage condition of MSCs has a great potential for the application of cell therapy.

\section{Introduction}

The use of mesenchymal stem cells (MSCs) is a potential regenerative therapeutic strategy because of their regenerative and immune-regulatory properties [1]. Currently MSCs are widely used in treating various diseases, including immune disorders, degenerative diseases, and tissue injuries [2,3]. Although MSCs can be derived from almost every tissue of the body $[4,5,6]$, adipose-derived MSCs (ADSCs) are ideal cells for further use in regenerative medicine due to the high abundance of ADSCs in adipose tissue and the minimal morbidity associated with harvesting MSCs from adipose tissue [7,8].

Large-scale application of MSCs in regenerative medicine demands clinically acceptable "off-the-shelf" cell therapy products. Stem cells cryopreserved using dimethyl sulfoxide (DMSO) are commonly used in regenerative medicine, however, a great number of observed adverse reactions were tenuously or convincingly associated with the cryoprotectant DMSO. Cerebral 
56 57 autologous stem cells with DMSO [9]. Neurotoxicity was observed in a patient who suffered

infarction and myocardial injury occurred in two patients after intravenous injection of from a generalized tonic seizure upon infusion of DMSO-cryopreserved peripheral blood stem cells [10]. During the infusion of hematopoietic stem cells without washing the DMSO a patient developed bradycardia, abdominal pain and nausea, and 24h later he developed anasarca and hypertension [11]. Other side effects caused by DMSO include cardiac arrest [12], severe respiratory arrest [13], paradoxical embolism [14], transient consciousness loss [15] and so on. There are several alternative cryoprotectants, such as ethylene glycol, methanol and polymer hydroxyethyl starch, but these would cause cell injury and researchers have to focus on how to minimize or eliminate their toxicity [16]. In addition, sometimes brief (i.e., 24-48h) storage of MSCs is needed, but cryopreservation of MSCs is not a practical way for brief storage of MSCs $[17,18,19,20]$. The short-term storage of fresh MSCs in $2 \sim 8^{\circ} \mathrm{C}$ does not require cryoprotectants which have underlying safety issues. Also it does not require complicated liquid nitrogen device, which means it can be used to improve the transportability of MSCs products.

\section{In order to maintain high quality of MSCs during the time between harvesting and} administration, the surrounding environment needs to be strictly controlled and some key factors must be taken into account [21]. Several factors including preservation media, durations of storage and cell concentrations may affect the viability and function of MSCs when suspended in liquid storage medium [20,22,23]. Different kinds of preservation media including M199 [24], PBS [25], NS [2], PlasmalyteA [23], 1\%HSA in DMEM20, 20\% HSA and 5\% glucose in 
Ringer's lactate [21] have been used in previous studies. However, M199 and PBS are not approved vehicles for safe injections thus they could not be used clinically. The viability of cells stored in $1 \%$ HSA in DMEM decreased rapidly [20]. There was no quality evaluation of the cells suspended in NS [2]. Transplantation of cells immediately after the harvest could receive best clinical outcomes because the quality of cells before administration affects therapeutic efficacy greatly. However, it takes hours or days to progress from harvest to transplantation inevitably [26]. Thus, it is of great importance to optimize an appropriate duration of storage with clinically acceptable cell viability and function. Although cell viability in 20\% HSA and $5 \%$ glucose in Ringer's lactate was high $(>80 \%)$ till $48 \mathrm{~h}$, there was no research on the proliferation and immunosuppressive capacity of MSCs [21]. It has been reported that cell concentrations may affect biological properties of hematopoietic stem cells and cell viability of non-MSC cell lines $[27,28]$. Thus we also evaluated the effects of cell concentrations during short-term storage on the characteristics of MSCs.

Short-term storage condition with high viability and function of ADSCs has not been studied systematically so far. We aimed to optimize a short-term storage condition to ensure the viability and function of ADSCs for therapeutic application.

\section{Materials \& Methods}

\section{Study design}


subsequent steps. In part I, the impact of different media was measured and the most suitable medium was subsequently used throughout the study. NS and PlasmalyteA are commonly used vehicles, and the supplement of HSA could protect cells from environmental stress and prevent adherence to the tubes or vials [29]. Dextrose provides a source of energy for cell metabolism [30]. Previous study reported that the best preservation medium for short-term storage was $5 \%$ dextrose [31]. Thus we decided to study $5 \%$ human serum albumin in $0.9 \%$ normal saline (NS+HSA), 5\% human serum albumin in multiple electrolytes (ME+HSA, as Baxter Healthcare Co., Ltd stopped production of PlasmalyteA here in China, ME with totally the same formula as PlasmalyteA was chosen to substitute PlasmalyteA.), dextrose and growth medium (GM) by measuring cell viability and cluster rates, adhesion ability, apoptosis and CFU capacity. In part II, two durations ( $24 \mathrm{~h}$ and $48 \mathrm{~h}$ ) of storage were evaluated by parameters described above and optimized duration was applied in the following study. In part III, cell concentrations were investigated by adopting measurement of proliferation and differentiation. In part IV, quantification of surface markers, cell cycle, IDO1 gene expression and Kyn concentration of ADSCs suspended in optimized concentration were studied. Cells were stored in $2 \mathrm{ml}$ cryogenic vials (Corning Incorporated, USA) and then placed in a cold chain shipping container designed to ensure stable cooled products transport $\left(2 \sim 8^{\circ} \mathrm{C}\right.$; more than $\left.50 \mathrm{~h}\right)$. A continuous temperature monitoring device was embedded in the cold chain shipping container. ADSCs were suspended after storage in $2 \sim 8^{\circ} \mathrm{C}$ for the following research. Unstored cells were fresh cells that did not undergo storage. 
115

116

117

118

119

120

121

122

123

124

125

126

127

\section{Preparation of storage media}

5\% (500ml: 25g) dextrose injection was purchased from Baxter Healthcare (Shanghai) Co., Ltd, China. NS+HSA was prepared by adding 5ml 20\%HSA (Shanghai Institute of Biological Products Co., Ltd, China) into 15ml NS (Hunan kelun Pharmaceutical Co., Ltd, China). ME+HSA was prepared by adding $5 \mathrm{ml} 20 \%$ HSA into $15 \mathrm{ml}$ ME (Sichuan kelun Pharmaceutical Co., Ltd, China). GM was a -modified minimal essential medium ( a -MEM, Gibco, USA) supplemented with 10\% fetal bovine serum (FBS, Gemini, Australia).

\section{Isolation and culture of ADSCS}

This study was approved by the Ethics Committee of the Shanghai First People's Hospital at Shanghai Jiao Tong University (number 2013KY080). The 33 years old woman volunteer signed the contract and permitted adipose tissue to be used for storage and scientific research. The first passage of ADSCs was separated and cultured in GMP condition in Shanghai Kun'ai Biological Technology Co., LTD. Cells were seeded in 6-well plates, cultured with a -MEM supplemented with $10 \%$ FBS and $1 \%$ penicillin/ streptomycin and maintained at $37^{\circ} \mathrm{C}$ in a humidified atmosphere at 5\% $\mathrm{CO}_{2}$. Medium was changed every three days. Cells were passaged at approximately $80 \%$ confluence and passages 3 to 5 were used for the experiments.

\section{Cell viability and apoptosis}

Cell viability and cluster rates were determined on an automatic cell counter (Countstar, Shanghai Ruiyu Biotech Co., Ltd, China) using trypan blue (Gibco, USA) staining method. 
134 Unstained cells were counted as live cells.

135

136

137

138

139

140

141

142

143

144

145

146

147

148

149

150

151

152

Cell apoptosis was analyzed using a FITC-conjugated Annexin V/PI assay kit (SAB, USA) as our previous study has reported [32]. 0.5million cells were rinsed twice with PBS. After centrifugation, $500 \mu 1$ buffer was added to suspend cells. $5 \mu 1$ Annexin V-FITC was added to the cell suspension and cells were incubated in the dark for $20 \mathrm{~min}$ at $4{ }^{\circ} \mathrm{C}$, followed by addition of $10 \mu 1 \mathrm{PI}$ and incubation in the dark for $5 \mathrm{~min}$ at $4^{\circ} \mathrm{C}$. Cell apoptosis was determined by flow cytometry (BD Bioscience, USA) and analyzed using FlowJo software (TreeStar, USA).

\section{Adhesion ability}

1million cells were seeded in a 100-mm cell culture dish (Corning Incorporated, USA) and allowed to attach for $24 \mathrm{~h}$ at $37^{\circ} \mathrm{C}$ in a humidified atmosphere at $5 \% \mathrm{CO}_{2}$. Cells were then observed and evaluated under an inverted microscope IX51 (Olympus, Japan).

\section{Colony-forming unit (CFU) capacity}

250cells suspended in 2ml a -MEM supplemented with 10\% FBS were seeded in a 60-mm dish(Corning Incorporated, USA) or per well of a six-well plate(Corning Incorporated, USA). After culture for 10 days at $37^{\circ} \mathrm{C}$ in a humidified atmosphere at $5 \% \mathrm{CO}_{2}$, cells were rinsed twice with PBS and fixed with methanol for $20 \mathrm{~min}$ at $-20^{\circ} \mathrm{C}$. Then methanol was removed and cells were rinsed twice with PBS. Cells were stained with $1 \mathrm{ml} 0.2 \%$ crystal violet (Sinopharm Chemical Reagent Ltd., China) for $1 \mathrm{~h}$ at room temperature. The plates were rinsed twice with PBS. Stained colonies with $>50$ cells were scored as CFU and counted under an inverted 
153 microscope.

154 Cell proliferation

155 Proliferation of ADSCs was assessed by a nontoxic metabolic indicator Alamar Blue (Life

156 technologies, USA) as our previous study has reported [33]. In brief, cells were seeded in a 24-

157 well plate (Corning Incorporated, USA) at a concentration of $2 \times 10^{4}$ cells $/$ well. After culture

158 for $24 \mathrm{~h}$, culture medium was changed into fresh medium containing $10 \%(\mathrm{v} / \mathrm{v})$ Alamar Blue

159 indicator and then cells were incubated in the dark for $3 \mathrm{~h}$ at $37^{\circ} \mathrm{C}$. Absorbance of the extracted

160 dye was measured by an enzyme immunoassay analyzer (Thermo, USA) at wavelengths of 570

161 and 590nm.

162 Population-doubling time (PDT) was calculated according to the following equation:

163

$P D T=t \times \lg 2 /\left(\lg N_{t}-\lg N_{0}\right)$

164 In the equation, $t$ indicated duration of proliferation, $N_{t}$ and $N_{0}$ represented harvesting cell

165 number and initial seeding cell number, respectively.

Differentiation assay

167 Adipogenic differentiation

168 Cells were seeded in a 12-well plate (Corning Incorporated, USA) at a concentration of

$1 \times 10^{4}$ cells/ well and cultured with a -MEM supplemented with $10 \%$ FBS until $80 \%$

170 confluency. Cells in differentiation group were incubated with adipogenic induction medium 
171

172

173

174

175

176

177

178

179

180

181

182

183

184

185

186

187

188

189

consisted of a -MEM supplemented with 10\% FBS, $1 \mu \mathrm{M}$ dexamethasone (Sigma, USA), $0.5 \mathrm{mM}$ isobutylmethylxanthine (Sigma, USA), $10 \mu \mathrm{M}$ insulin (Sigma, USA) and $200 \mu \mathrm{M}$ indomethacin (Sigma, USA). Cells in control group were cultured with a -MEM supplemented with $10 \%$ FBS. Medium was changed every 3 days. After incubation for 3 weeks, cells were stained by Oil Red O (Sigma, USA) and observed under an inverted microscope. Then adipogenic differentiation was quantified by an enzyme immunoassay analyzer at $510 \mathrm{~nm}$ after the elution with isopropyl alcohol for $10 \mathrm{~min}$ at room temperature.

\section{Osteogenic differentiation}

Cells were seeded in a 12-well plate at a concentration of $5 \times 10^{3}$ cells /well and cultured with a -MEM supplemented with 10\% FBS until $80 \%$ confluency. Cells in differentiation group were incubated with osteogenic induction medium consisted of a -MEM supplemented with $10 \%$ FBS, $0.1 \mu \mathrm{M}$ dexamethasone, 10mM $\beta$-glycerophosphate (Sinopharm Chemical Reagent Ltd., China) and $200 \mu \mathrm{M}$ ascorbic acid (Sigma, USA). Cells in control group were cultured with a MEM supplemented with 10\% FBS. Medium was changed every 3 days. After incubation for 3 weeks, cells were stained by Alizarin red (Chroma-Schmidt GmbH, Germany) and observed under an inverted microscope. Then osteogenic differentiation was quantified by an enzyme immunoassay analyzer at $570 \mathrm{~nm}$ after the solubilization with $10 \%$ cetylpyridinium chloride (Sigma, USA) for $10 \mathrm{~min}$ at room temperature.

Quantification of surface markers 

phycoerythrin-(PE)-labeled HLA-DR, CD 34, CD45, CD73, CD90 and CD105. The control for

PE-coupled antibodies was isotypic mouse IgG1. The data were evaluated using CellQuest software (BD Biosciences, USA) and analyzed by FlowJo software. determined by flow cytometry and analyzed using FlowJo software.

Immunosuppressive capacity index which could reflect IDO1 activity. 
209 induced for $24 \mathrm{~h}$. In control group, unstored cells were seeded in a six-well plate, and then treated

210 using the same method as stored cells. Cells were used for IDO1 gene expression assay and

211 supernatant was collected for Kyn concentration assay.

\section{IDO1 gene expression}

After incubation for 24h, total RNA was extracted from ADSCs using RNAiso Plus Kit

214 (Takara, Japan) following the manufacturer's protocol. Total RNA concentrations were

215

216 quantified using NanoDrop1000 (Thermo, USA). $1 \mu \mathrm{g}$ total RNA was reserved. Real-time polymerase chain reaction (PCR) was achieved by SYBR green system (Takara, Japan). Amplifications for cDNA samples were carried out at $95^{\circ} \mathrm{C}$ for $30 \mathrm{~s}$, followed by 40 cycles at $95^{\circ} \mathrm{C}$ for $5 \mathrm{~s}$ and at $60^{\circ} \mathrm{C}$ for $30 \mathrm{~s}$. Primer sequences were listed in Table 1 . The relative quantification of target gene was calculated using the $2^{-\triangle \Delta t}$ method and normalized to the transcript levels of glyceraldehyde 3-phosphate dehydrogenase (GAPDH). Melting curve profiles were produced at the end of each PCR to confirm the specific transcriptions of amplification [33].

\section{Kyn concentration}

$1 \mathrm{ml}$ cell supernatant was mixed with $250 \mu 130 \%$ trichloroacetic acid (Sinopharm Chemical Reagent Ltd., China) and the mixture was vortexed and centrifuged at $12000 \mathrm{rpm}$ for $20 \mathrm{~min}$ at $4^{\circ} \mathrm{C}$. After filtration with $0.22 \mu \mathrm{M}$ membrane (Life Science, USA), supernatant was analyzed by high performance liquid chromatography LC-20AT (HPLC, Shimadzu, Japan) equipped with a Phenomenex Gemini C18 $(250 \times 4.6 \mathrm{~mm}, 5 \mu \mathrm{m})$ column. Mobile phase A was $1 \mu \mathrm{mol} / 1$ 
228

229

230

231

232

233

234

235

236

237

238

239

240

241

242

243

244

245

246

potassium dihydrogen phosphate $(\mathrm{pH}=4$, Sinopharm Chemical Reagent Ltd., China) and mobile phase B was methanol (Merck, USA). The rate of mobile phase A and B was 3:1 and the flow rate was $1 \mathrm{ml} / \mathrm{min}$. Kyn concentration was detected by the UV-detector at a wavelength of $360 \mathrm{~nm}$ at room temperature.

\section{Statistical analysis}

All data were shown as mean \pm standard deviation, and difference and significance were verified by an one-way analysis of variance (ANOVA), followed by the least-square difference (LSD) for multiple comparisons test. A level of significance of $\mathrm{P}<0.05$ was used to indicate statistical differences. The statistical analysis was performed using SPSS 19 (SPSS Inc., USA).

\section{Results}

\section{Part I: Evaluation of preservation media}

Harvested ADSCs were suspended in dextrose, ME+HSA, NS+HSA and GM at a concentration of $1 \times 10^{6}$ cells $/ \mathrm{ml}$. After storage for $24 \mathrm{~h}$ at $2 \sim 8^{\circ} \mathrm{C}$, cells were used for the following research. Unstored cells were used as control.

The viability of cells in ME+HSA (95.88 $\pm 0.69 \%)$ and NS+HSA $(91.96 \pm 1.53 \%)$ were significantly higher than in dextrose $(67.81 \pm 6.37 \%)$ (Fig. $1 \mathrm{~A}, \mathrm{P}<0.05)$. Cell viability in dextrose dropped off dramatically after storage for $24 \mathrm{~h}$. The cluster rate of cells in GM $(26.99 \pm 1.84 \%)$ was significantly higher than that of cells in ME+HSA $(3.44 \pm 0.81 \%)$, NS+HSA $(4.23 \pm 2.46 \%)$ and dextrose $(3.82 \pm 0.04 \%$ ) (Fig. 1A, $\mathrm{P}<0.05)$. As shown in Fig. 1A, cells in GM clustered 
247

248

249

250

251

252

253

254

255

256

257

258

259

260

261

262

263

264

265

obviously. These results indicated that dextrose, with low cell viability, and GM, with extremely

high cluster rate, were not suitable media for the storage of ADSCs.

In our subsequent observation, we found the viability of cells after storage measured by trypan blue staining was not precise and sensitive enough, so we performed Annexin V/PI binding assay (Fig. 1B). The proportions of normal cells in dextrose, ME+HSA, NS+HSA and GM all decreased but there were no significant differences among them. The proportions of early stage apoptotic cells and late stage apoptotic cells both increased in dextrose, ME+HSA, NS+HSA and GM, but there were no significant differences among them, respectively.

The adhesion ability of ADSCs after storage was observed under an inverted microscope (Fig. 1C). Attached cells in the four groups after storage all showed similar spindle-shaped morphologies to cells in the unstored group. However, a mass of detached cells were obviously observed in NS+HSA, which indicated that a lot of cells lost their adhesion ability after storage in NS+HSA.

An evaluation of CFU capacity was performed on ADSCs (Fig. 1D). All groups could form colonies with $>50$ cells after culture for 10 days. However, the CFU of cells in ME+HSA $(13.33 \pm 2.05)$ was significantly higher than that of cells in NS+HSA $(2.40 \pm 1.06)$. These results indicated that ME+HSA was a better preservation medium than NS+HSA.

Based on the study of different preservation media, ME+HSA was selected as a proper preservation medium for high cell viability, low cell cluster rate, good adhesion ability and high 
266 CFU capacity.

\section{Part II: Evaluation of durations of storage}

ME+HSA was selected as the storage medium for further study. The storage of ADSCs in

$\mathrm{ME}+\mathrm{HSA}$ for durations of $24 \mathrm{~h}$ and $48 \mathrm{~h}$ at $4^{\circ} \mathrm{C}$ at a concentration of $1 \times 10^{6} \mathrm{cells} / \mathrm{ml}$ were studied.

Unstored cells were used as control.

The cell viability after storage for $48 \mathrm{~h}(95.34 \pm 4.72 \%)$ was very high and there was no significant difference compared to cells stored for $24 \mathrm{~h}(98.11 \pm 1.33 \%)$, as data were shown in

Fig. S1. The cluster rate was lower after storage for $48 \mathrm{~h}(7.98 \pm 1.20 \%)$ than after storage for $24 \mathrm{~h}$ $(15.06 \pm 1.34 \%)$. It seemed that cells could be stored in ME+HSA with high viability. apoptotic cells increased notably over storage time from $24 \mathrm{~h}(29.13 \pm 3.22 \%)$ to $48 \mathrm{~h}$ early to late stage apoptosis.

Although the spindle-shaped morphology of attached cells did not change over the storage time (Fig. 2B), there were significantly fewer attached cells following storage for $48 \mathrm{~h}$ than for 
285 number of these colonies formed after storage for $48 \mathrm{~h}(8.67 \pm 1.67)$ was obviously lower than 286 that for $24 \mathrm{~h}(17.07 \pm 4.01)$.

In conclusion, cells could not be stored in ME+HSA for $48 \mathrm{~h}$ due to high level of apoptosis, poor adhesion ability and low CFU capacity although viability of cells suspended in ME+HSA for $48 \mathrm{~h}$ was very high. $24 \mathrm{~h}$ was shown to be an appropriate duration of storage, with relatively low proportion of late stage apoptosis, high adhesion ability and CFU capacity.

Part III: Evaluation of cell concentrations

ADSCs suspended in ME+HSA were stored for $24 \mathrm{~h}$ at $2 \sim 8^{\circ} \mathrm{C}$ at various concentrations:

$1 \times 10^{6} \mathrm{cell} / \mathrm{s} / \mathrm{ml}, 5 \times 10^{6} \mathrm{cell} / \mathrm{ml}$ and $10 \times 10^{6} \mathrm{cells} / \mathrm{ml}$. Unstored cells were used as control. normal cells decreased obviously as the cell concentration increased from $1 \times 10^{6} \mathrm{cells} / \mathrm{ml}$ $(50.6 \pm 3.66 \%)$ to $10 \times 10^{6}$ cells $/ \mathrm{ml}(37 \pm 0.75 \%)$. Cells at a concentration of $5 \times 10^{6} \mathrm{cells} / \mathrm{ml}$ $(30.40 \pm 2.87 \%)$ showed obviously higher level of early stage apoptosis than cells at $1 \times 10^{6} \mathrm{cells} / \mathrm{ml}(19.80 \pm 4.16 \%)$ and $10 \times 10^{6} \mathrm{cells} / \mathrm{ml}(23.33 \pm 3.66 \%)(\mathrm{P}<0.05)$. Cells at concentrations of $1 \times 10^{6} \mathrm{cells} / \mathrm{ml}(29.13 \pm 3.22 \%)$ and $5 \times 10^{6} \mathrm{cells} / \mathrm{ml}(26.37 \pm 7.43 \%)$ showed lower level of late stage apoptosis than cells at $10 \times 10^{6} \mathrm{cells} / \mathrm{ml}(40.60 \pm 3.78 \%)$. These results indicated that cells stored at the concentration of $10 \times 10^{6} \mathrm{cells} / \mathrm{ml}$ would cause the highest level of late stage apoptosis. 
304

305

306

307

308

309

310

311

312

313

314

seemed that there were no significant differences in adhesion ability among cells at three cell concentrations.

Cells could form colonies with $>50$ cells at all three concentrations (Fig. 3C). There were no obvious differences in CFU numbers among cells suspended at $1 \times 10^{6} \mathrm{cells} / \mathrm{ml}(17.07 \pm 4.01)$, $5 \times 10^{6} \mathrm{cells} / \mathrm{ml}(13.00 \pm 1.40)$ and $10 \times 10^{6} \mathrm{cells} / \mathrm{ml}(15.47 \pm 1.29)$. These results indicated that cell concentrations during the storage period did not impact on the CFU capacity.

Proliferation ability was shown in Fig. 4. The fluorescence value reached the peak at the $7^{\text {th }}$ day in unstored cells and the PDT was $57.57 \pm 4.77 \mathrm{~h}$. The fluorescence values increased slowly until the $4^{\text {th }}$ day in group $5 \times 10^{6} \mathrm{cell} / \mathrm{s} / \mathrm{ml}$ and group $10 \times 10^{6} \mathrm{cell} \mathrm{s} / \mathrm{ml}$, and then increased rapidly until reaching the peak on the $9^{\text {th }}$ day with the PDT of $79.05 \pm 6.74 \mathrm{~h}$ and $81.07 \pm 7.84 \mathrm{~h}$, respectively. There was no significant difference between group $5 \times 10^{6} \mathrm{cells} / \mathrm{ml}$ and group $10 \times 10^{6} \mathrm{cells} / \mathrm{ml}$, in terms of either fluorescence values or PDT. As the fluorescence value in group $1 \times 10^{6} \mathrm{cell} \mathrm{s} / \mathrm{ml}$ increased slowly with the time, it did not reach its peak before we stopped our measurement on the $10^{\text {th }}$ day. These results indicated that cells in group $1 \times 10^{6} \mathrm{cells} / \mathrm{ml}$ had low proliferation potential.

All of these three groups at different concentrations showed osteogenic differentiation (Fig. 5A) and adipogenic differentiation abilities (Fig. 5B). Osteogenic differentiation in group $5 \times 10^{6} \mathrm{cells} / \mathrm{ml}(0.09 \pm 0.01)$ was slightly higher than in group $1 \times 10^{6} \mathrm{cell} / \mathrm{s} / \mathrm{ml}(0.07 \pm 0.01)$ or group $10 \times 10^{6} \mathrm{cells} / \mathrm{ml}(0.07 \pm 0.01)$. Adipogenic differentiation ability in group $5 \times 10^{6} \mathrm{cell} / \mathrm{s} / \mathrm{ml}$ $(0.34 \pm 0.03)$ was obviously higher than in group $1 \times 10^{6} \mathrm{cells} / \mathrm{ml}(0.18 \pm 0.02)$ and group 
$32410 \times 10^{6} \mathrm{cells} / \mathrm{ml}(0.16 \pm 0.01)(\mathrm{P}<0.05)$. These results suggested that group $5 \times 10^{6} \mathrm{cells} / \mathrm{ml}$ had 325 the best differentiation potential.

326 Level of apoptosis increased when the cell concentration increased from $1 \times 10^{6}$ cells $/ \mathrm{ml}$ to

$32710 \times 10^{6} \mathrm{cells} / \mathrm{ml}$. It seemed there were no obvious differences among the three groups in terms of 328 adhesion ability or CFU capacity. Thus, we adopted the assays of proliferation and

329 differentiation as two further evaluation parameters. Proliferation assay of group $1 \times 10^{6} \mathrm{cell} / \mathrm{s} / \mathrm{ml}$

330 showed that low concentration would slower the growth of ADSCs and cells in group

$3315 \times 10^{6} \mathrm{cells} / \mathrm{ml}$ showed best osteogenic and adipogenic differentiation potential. These results

332 suggested that $5 \times 10^{6}$ cells $/ \mathrm{ml}$ was a suitable cell concentration for short-term storage.

Part IV: Evaluation of optimized condition

After the selection of preservative media, durations of storage and cell concentrations, we decided to store ADSCs in ME+HSA for $24 \mathrm{~h}$ at a concentration of $5 \times 10^{6}$ cells $/ \mathrm{ml}$ in $2 \sim 8^{\circ} \mathrm{C}$. In order to give a comprehensive evaluation of our optimized condition, we studied the surface markers, cell cycle and immunosuppressive capacity of ADSCs after storage. Unstored cells were used as control.

After storage, HLA-DR, CD34 and CD45 were all negatively expressed $(<2 \%)$, while CD73, CD90 and CD105 were all positively expressed (>95\%, Fig. 6A). These results indicated that the storage of this optimized condition did not affect the expression of surface markers.

\footnotetext{
Flow cytometric analysis of cell cycle distribution was shown in Fig. 6B. After the storage,
} 
343 there were no significant differences in G0/G1, S and G2/M compared with unstored cells,

344 respectively. These results indicated that this optimized condition did not change the cell cycle

345 distribution.

There was no significant fold difference in IDO1 gene expression between stored cells

347 (3393.54 \pm 653.65$)$ and unstored cells (3654.41 \pm 136.30 , Fig. 6C). Also, there were no obvious differences in Kyn concentration between unstored cells (25.24 \pm 1.75$)$ and stored cells (27.45 \pm 2.31 , Fig. $6 \mathrm{D})$. These results indicated that this optimized condition did not change gene expression and activity of IDO1.

\section{Discussion}

Adipose tissue was considered to be merely a passive energy store in previous years, before ADSCs could be isolated from adipose tissue as a new source of stem cells in 2001 [34]. ADSCs are multipotent cells with the ability to differentiate into both mesodermal and non-mesodermal lineages, similar to bone marrow-derived stem cells (BM-MSCs). In addition, ADSCs have a great number of advantages over BM-MSCs. ADSCs could be collected in large quantity with minimal morbidity [35], and derivation of ADSCs is easier(less invasive) and much more efficient than that of BM-MSCs. Thus ADSCs are attractive stem cells for regenerative application.

In order to manufacture a clinical-scale large number of ADSCs for cell therapy in regenerative medicine and tissue engineering, strictly quality control is required which means 
362

363

364

365

366

367

368

369

370

371

372

373

374

375

376

377

378

379

380

381

that a cGMP-compliant clean room is needed. It seems impossible to build an expensive cGMPcompliant clean room in the hospital set-up, thus cell products should be produced in a central laboratory for up-scaling cells and then transported to the bedside of the patient [31]. Although cryopreservation is an alternative for long-term storage of ADSCs, its requirement for toxic cryoprotectants (i.e. DMSO) and low recovery rate of cells demonstrated that it is not the best or the safest condition for the short-term storage of cell products $[23,36]$. There is no standard protocol for short-term storage of fresh cells before transplantation as well as no relatively comprehensive evaluation of cell quality after storage. Previous study reported that MSCs stored in saline or dextrose for more than $2 \mathrm{~h}$ lost cell viability significantly. MSCs lost CFU capacity and differentiation ability rapidly as storage time increased. Thus duration of storage was limited to $2 \mathrm{~h}$ to ensure the quality of MSCs [26]. Although Plasmalyte A, 1\% HSA and 5\% HSA were FDA approved injections and typically used as preservation media prior to MSCs transplantation, none of these single components supported the survival of MSCs [23]. No duration information was given in a clinical trial of MSCs stored in saline for the treatment of ischemic stroke [37]. Cell concentration was considered to have an impact on cell quality, but researchers only measured MSCs counts among cells at the concentrations over a range of $0.5 \times 10^{6}$ to $20 \times 10^{6}$ cells $/ \mathrm{ml}$ as the evaluation of cell quality [20]. Other researchers reported few or no details about preservation conditions or the effect of short-term storage on MSCs [38,39,40,41]. The primary objective of this study was to optimize preservation media, durations of storage and cell concentrations of ADSCs to provide a feasible short-term storage condition for cell therapy. 

confirmed the natural preference of MSCs to form aggregates [42]. Thus it would be unsafe clinically to inject cells suspended in GM. In addition, FBS in GM remains associated with safety issues including transmission of viral disease, anaphylactic reactions and production of anti-FBS antibodies $[29,43,44]$. Therefore, GM is not a suitable preservation medium for the short-term storage of ADSCs. When stored in dextrose, dark blue stained cells could be seen obviously. The viability of ADSCs suspended in dextrose decreased to $67.81 \pm 6.37 \%$, which was lower than the minimum viability $(70 \%)$ acceptable by FDA for cell therapy. The deterioration of ADSCs survival in dextrose may be caused by the low-pH level (3.2-5.5).

Additionally, high concentration of $5 \%$ dextrose $(50 \mathrm{~g} / \mathrm{L})$ affects regenerative potential of MSCs and induces replicative senescence [23]. The adhesion ability and CFU capacity of ADSCs in

NS+HSA were obviously lower than in ME+HSA respectively, despite the fact that the viability and apoptosis of cells in NS+HSA had no significant differences compared to cells in ME+HSA respectively. Thus a comprehensive evaluation system was needed to test the quality of cells before administration as rapid detection of viability and apoptosis would not always be reliable

ME could provide energy for cell survival. 
402

403

404

405

406

407

408

409

410

411

412

413

414

415

416

417

418

419

420

421

enough for the transport of cell products to another city thousands of kilometers away and for the preparation of both patients and doctors. We also wanted to investigate the longest duration with $>70 \%$ cell viability. Results showed that the viability of cells in $48 \mathrm{~h}$ was high ( $>90 \%)$, however, the late stage apoptosis rate in $48 \mathrm{~h}$ was also high $(41.53 \pm 1.15 \%)$. The adhesion ability was poor and CFU capacity was low $(8.67 \pm 1.67)$. High level of late stage apoptosis, poor adhesion ability and low CFU capacity showed that cells could not adequately be stored for $48 \mathrm{~h}$. These results may be a consequence of reduced nutrient supply and increase in waste and lactic acid accumulation during prolonged storage [45]. The late stage apoptosis of cells $(29.13 \pm 3.22 \%)$ stored for $24 \mathrm{~h}$ was acceptable, and the CFU number (17.07 \pm 4.01$)$ of cells stored for $24 \mathrm{~h}$ was relatively high. All these results suggested that cells suspended in ME+HSA could be stored for 24h before administration.

Cell concentration during the storage is also an important factor which may affect cell quality. Compared to intravenous injection, subcutaneous injection and intramuscular injection require higher concentrated cell products with smaller volumes. As previous study has reported [28], MSCs suspension injected into small tendinous lesions would leak outside the defect and into the peritendinous tissue even the volume of cell suspension was only $1 \mathrm{ml}$. Thus cell products of high cell concentration are needed. We compared three cell concentrations $1 \times 10^{6} \mathrm{cells} / \mathrm{ml}, \quad 5 \times 10^{6} \mathrm{cells} / \mathrm{ml}$ and $10 \times 10^{6} \mathrm{cells} / \mathrm{ml}$. Late stage apoptotic rate increased as the cell concentration increased. We didn't observed significantly differences among these three groups in terms of adhesion ability and CFU capacity. Thus, we adopted the evaluation of 
422

423

424

425

426

proliferation and differentiation. The proliferation of cells stored at a concentration of $5 \times 10^{6} \mathrm{cells} / \mathrm{ml}$ was very close to that of cells stored at $10 \times 10^{6} \mathrm{cells} / \mathrm{ml}$ and significantly faster than that of cells stored at $1 \times 10^{6} \mathrm{cells} / \mathrm{ml}$. Cells stored at $5 \times 10^{6} \mathrm{cells} / \mathrm{ml}$ showed the best osteogenic and adipogenic differentiation potential. The high level of late stage apoptosis of cells stored at $10 \times 10^{6} \mathrm{cells} / \mathrm{ml}$ may be explained that the highest cell concentration may be associated with the fastest lactic acid accumulation [46]. To some extent, decreasing cell concentration to limit lactic acid accumulation could enhance cell viability and improve cell function [22]. Longterm proliferation kinetics results indicated that the proliferation potential of cells stored at $1 \times 10^{6} \mathrm{cells} / \mathrm{ml}$ was impaired. Although increasing cell concentration could improve the proliferation potential, it seemed $5 \times 10^{6} \mathrm{cells} / \mathrm{ml}$ was high enough as the curve of it was very close to that of $10 \times 10^{6} \mathrm{cells} / \mathrm{ml}$. Osteogenic and adipogenic differentiation results also suggested that $5 \times 10^{6} \mathrm{cells} / \mathrm{ml}$ was a suitable cell concentration. As previous study have reported the same cell concentration of $5 \times 10^{6} \mathrm{cell} / \mathrm{s} / \mathrm{ml}$ as our result for cell therapy [47,48], we thought cells suspended at $5 \times 10^{6} \mathrm{cells} / \mathrm{ml}$ could have the highest quality among these three concentrations. After the evaluation of preservation media, durations of storage and cell concentrations, we thought cells suspended in ME+HSA at a concentration of $5 \times 10^{6} \mathrm{cell} / \mathrm{s} / \mathrm{ml}$ could be stored for $24 \mathrm{~h}$ at $2 \sim 8^{\circ} \mathrm{C}$ before administration. Then we evaluated this condition by studying surface markers, cell cycle and immunosuppressive capacity of ADSCs after storage. Results showed that surface markers, cell cycle and immunosuppressive capacity did not change after the storage, which confirmed our result that this optimized condition has a great potential for the short-term 
442 storage of MSCs for cell therapy.

\section{Conclusions}

444 This is the first study to optimize a short-term storage condition of ADSCs comprehensively.

445 Key factors during short-term storage including preservation media, durations and cell

446 concentrations are studied. Comprehensive evaluation is needed to reflect real cell status before

447 transplantation. Our results show that ADSCs suspended in ME+HSA, at a concentration of

$4485 \times 10^{6} \mathrm{cells} / \mathrm{ml}$ could be stored for $24 \mathrm{~h}$ at $2 \sim 8^{\circ} \mathrm{C}$, which provides a reliable short-term storage

449 condition for cell therapy. Future studies are still needed to improve cell viability, extend

450 duration of storage, and verify the therapeutic effect of ADSCs after short-term storage in vivo. 


\section{References}

[1] M Kaplan J, E Youd M, A Lodie T. 2011. Immunomodulatory activity of mesenchymal stem cells. Current stem cell research \& therapy 6(4): 297-316. DOI: 10.2174/157488811797904353.

[2] Venkataramana N K, Kumar S K V, Balaraju S, Radhakrishnan R C, Bansal A, Dixit A, Rao D K, Das M, Jan M, Gupta P K, Totey S M. 2010. Open-labeled study of unilateral autologous bone-marrow-derived mesenchymal stem cell transplantation in Parkinson's disease. Translational Research 155(2): 62-70.DOI: 10.1016/j.trsl.2009.07.006.

[3] Wei X, Yang X, Han Z, Qu F, Shao L, Shi Y. 2013. Mesenchymal stem cells: a new trend for cell therapy. Acta Pharmacologica Sinica 34(6): 747-754. DOI: 10.1038/aps.2013.50.

[4] da Silva Meirelles L, Chagastelles P C, Nardi N B. 2006. Mesenchymal stem cells reside in virtually all post-natal organs and tissues. Journal of cell science 119(11): 2204-2213. DOI: 10.1242/jcs.02932.

[5] Kern S, Eichler H, Stoeve J, Klüter H, Bieback K. 2006. Comparative analysis of mesenchymal stem cells from bone marrow, umbilical cord blood, or adipose tissue. Stem cells 24(5): 1294-1301. DOI: 10.1634/stemcells.2005-0342.

[6] Mosna F, Sensebé L, Krampera M. 2010. Human bone marrow and adipose tissue mesenchymal stem cells: a user's guide. Stem cells and development 19(10): 1449-1470. DOI:10.1089/scd.2010.0140.

[7] Bajek A, Gurtowska N, Olkowska J, Kazmierski L, Maj M, Drewa T. 2016. Adipose-Derived stem cells as a Tool in Cell-Based therapies. Archivum immunologiae et therapiae experimentalis 64(6): 443-454. DOI:10.1007/s00005-016-0394-X.

[8] Gomez-Mauricio R G, Acarregui A, Sánchez-Margallo F M, Crisóstomo V, Gallo I, Hernández R M, Pedraz J L. 2013. A preliminary approach to the repair of myocardial infarction using adipose tissuederived stem cells encapsulated in magnetic resonance-labelled alginate microspheres in a porcine model. European Journal of Pharmaceutics and Biopharmaceutics 84(1): 29-39. DOI: 10.1016/j.ejpb.2012.11.028.

[9] Chen-Plotkin A S, Vossel K A, Samuels M A, Chen M H. 2007. Encephalopathy, stroke, and myocardial infarction with DMSO use in stem cell transplantation. Neurology 68(11): 859-861. DOI:

10.1212/01.wnl.0000256716.04218.5b.

[10] Mueller L P, Theurich S, Christopeit M, Grothe W, Muetherig A, Weber T, Guenther S, Behre G. 2007. Neurotoxicity upon infusion of dimethylsulfoxide - cryopreserved peripheral blood stem cells in patients with and without pre - existing cerebral disease. European journal of haematology 78(6): 527-531. DOI: 10.1111/j.1600-0609.2007.00851.x.

[11] Ruiz-Delgado G J, Mancías-Guerra C, Tamez-Gómez E L, Rodríguez-Romo L N, López-Otero A, Hernández-Arizpe A, Gómez-Almaguer D, Ruiz-Argüelles G J. 2009. Dimethyl sulfoxide-induced toxicity in cord blood stem cell transplantation: report of three cases and review of the literature. Acta haematologica 122(1): 1-5. DOI: 10.1159/000227267. 
[12] Rapoport A P, Rowe J M, Packman C H, Ginsberg S J.1991.Cardiac arrest after autologous marrow infusion. Bone marrow transplantation 7(5): 401-403.

[13] Benekli M, Anderson B, Wentling D, Bernstein S, Czuczman M, McCarthy P. 2000. Severe respiratory depression after dimethylsulphoxide-containing autologous stem cell infusion in a patient with $\mathrm{AL}$ amyloidosis. Bone marrow transplantation 25(12).DOI: 10.1038/sj.bmt.1702452.

[14] Darabi K, Brown J R, Kao G S. 2005. Paradoxical embolism after peripheral blood stem cell infusion. Bone marrow transplantation 36(6): 561-562.DOI: 10.1038/sj.bmt.1705088.

[15] Schlegel P G, Wölfl M, Schick J, Winkler B, Eyrich M. 2009. Transient loss of consciousness in pediatric recipients of dimethylsulfoxide (DMSO)-cryopre-served peripheral blood stem cells independent of morphine co-medication. Haematologica 94(10): 1473-1475. DOI: 10.3324/haematol.2009.009860.

[16] Marquez-Curtis L A, Janowska-Wieczorek A, McGann L E, Elliott J A. 2015. Mesenchymal stromal cells derived from various tissues: biological, clinical and cryopreservation aspects. Cryobiology 71(2): 181-197. DOI: 10.1016/j.cryobiol.2015.07.003.

[17] Haack-Sorensen M, Bindslev L, Mortensen S, Friis T, Kastrup J. 2007. The influence of freezing and storage on the characteristics and functions of human mesenchymal stromal cells isolated for clinical use. Cytotherapy 9(4): 328-337. DOI: 10.1080/14653240701322235.

[18] Lazarus H M, Koc O N, Devine S M, Curtin P, Maziarz R T, Holland H K, Shpall E J, McCarthy P, Atkinson K,Cooper B W, Gerson S L, Laughlin M J, Loberiza F R Jr, Moseley A B, Bacigalupo A. 2005. Cotransplantation of HLA-identical sibling culture-expanded mesenchymal stem cells and hematopoietic stem cells in hematologic malignancy patients. Biology of blood and marrow transplantation 11(5): 389398. DOI: 10.1016/j.bbmt.2005.02.001.

[19] Kim D W, Chung Y J, Kim T G, Kim Y L, Oh I H. 2004. Cotransplantation of third-party mesenchymal stromal cells can alleviate single-donor predominance and increase engraftment from double cord transplantation. Blood 103(5): 1941-1948.DOI: 10.1182/blood-2003-05-1601.

[20] Lane T A, Garls D, Mackintosh E, Kohli S, Cramer S C. 2009. Liquid storage of marrow stromal cells. Transfusion 49(7): 1471-1481. DOI: 10.1111/j.1537-2995.2009.02138.x.

[21] Gálvez-Martín P, Hmadcha A, Soria B, Calpena-Campmany AC, Clares-Naveros B. 2014. Study of the stability of packaging and storage conditions of human mesenchymal stem cell for intra-arterial clinical application in patient with critical limb ischemia. European Journal of Pharmaceutics and Biopharmaceutics 86(3): 459-468. DOI: 10.1016/j.ejpb.2013.11.002.

[22] Kao G S, Kim H T, Daley H, Ritz J, Burger S R, Kelley L, Vierra-Green C, Flesch S, Spellman S, Miller J,Confer D. 2011. Validation of short - term handling and storage conditions for marrow and peripheral blood stem cell products. Transfusion 51(1): 137-147. DOI: 10.1111/j.1537-2995.2010.02758.x.

[23] Chen Y, Yu B, Xue G, Zhao J, Li RK, Liu Z, Niu B. 2013. Effects of storage solutions on the viability of human umbilical cord mesenchymal stem cells for transplantation. Cell transplantation 22(6): 1075-1086. DOI: $10.3727 / 096368912 X 657602$.

[24] Mohamadnejad M, Alimoghaddam K, Mohyeddin-Bonab M, Bagheri M, Bashtar M, Ghanaati 
$\mathrm{H}$,Baharvand H, Ghavamzadeh A, Malekzadeh R. 2007. Phase 1 trial of autologous bone marrow mesenchymal stem cell transplantation in patients with decompensated liver cirrhosis. Arch Iran Med 10(4): 459-466. DOI: 07104/AIM.008.

[25] Wang D, Zhang F, Shen W, Chen M, Yang B, Zhang Y, Cao K. 2011. Mesenchymal stem cell injection ameliorates the inducibility of ventricular arrhythmias after myocardial infarction in rats. International journal of cardiology 152(3): 314-320. DOI: 10.1016/j.jjcard.2010.07.025.

[26] Sohn H S, Heo J S, Kim H S, Choi Y, Kim H O. 2013. Duration of in vitro storage affects the key stem cell features of human bone marrow-derived mesenchymal stromal cells for clinical transplantation. Cytotherapy 15(4): 460-466. DOI: 10.1016/j.jcyt.2012.10.015.

[27] De Loecker W, Koptelov V A, Grischenko V I, De Loecker P. 1998. Effects of cell concentration on viability and metabolic activity during cryopreservation. Cryobiology 37(2): 103-109. DOI: 10.1006/cryo.1998.2106.

[28] Espina M, Jülke H, Brehm W, Ribitsch I, Winter K, Delling U. 2016. Evaluation of transport conditions for autologous bone marrow-derived mesenchymal stromal cells for therapeutic application in horses. PeerJ 4: e1773. DOI: 10.7717/peerj.1773.

[29] Ikebe C, Suzuki K. 2014. Mesenchymal stem cells for regenerative therapy: optimization of cell preparation protocols. BioMed research international 2014. DOI: 10.1155/2014/951512.

[30] Anderson R V, Siegman M G, Balaban R S,Ceckler T L, Swain J A. 1992. Hyperglycemia increases cerebral intracellular acidosis during circulatory arrest. The Annals of thoracic surgery 54(6): 1126-1130.

[31] Pal R, Hanwate M, Totey S M. 2008. Effect of holding time, temperature and different parenteral solutions on viability and functionality of adult bone marrow - derived mesenchymal stem cells before transplantation. Journal of tissue engineering and regenerative medicine 2(7): 436-444. DOI: 10.1002/term.109.

[32] Ren H, Sang Y, Zhang F, Liu Z, Qi N, Chen Y. 2016. Comparative analysis of human mesenchymal stem cells from umbilical cord, dental pulp, and menstrual blood as sources for cell therapy. Stem cells international 2016. DOI: 10.1155/2016/3516574.

[33] Chen Y, Zhang F, Fu Q, Liu Y, Wang Z, Qi N. 2016. In vitro proliferation and osteogenic differentiation of human dental pulp stem cells in injectable thermo-sensitive chitosan/betaglycerophosphate/hydroxyapatite hydrogel. Journal of biomaterials applications 31:317-27. DOI: $10.1177 / 0885328216661566$.

[34] Zuk P A, Zhu M, Mizuno H, Huang J, Futrell J W, Katz A J, Benhaim P, Lorenz H P, Hedrick M H. 2001. Multilineage cells from human adipose tissue: implications for cell-based therapies. Tissue engineering 7(2): 211-228. DOI: 10.1089/107632701300062859.

[35] Uzbas F, May I D, Parisi A M, Thompson S K, Kaya A, Perkins A D, Memili E. 2015. Molecular physiognomies and applications of adipose-derived stem cells. Stem Cell Reviews and Reports 11(2): 298-308. DOI: 10.1007/s12015-014-9578-0.

[36] Grein T A, Freimark D, Weber C, Hudel K, Wallrapp C, Czermak P. 2010. Alternatives to 
dimethylsulfoxide for serum-free cryopreservation of human mesenchymal stem cells. The International journal of artificial organs 33(6): 370-380.

[37] Bang O Y, Lee J S, Lee P H, Lee G. 2005. Autologous mesenchymal stem cell transplantation in stroke patients. Annals of neurology 57(6): 874-882. DOI: 10.1002/ana.20501.

[38] Li Y, Chen J, Chen X G, Wang L, Gautam S C, Xu Y X, Katakowski M, Zhang L J, Lu M, Janakiraman $\mathrm{N}$,Chopp M. 2002. Human marrow stromal cell therapy for stroke in rat neurotrophins and functional recovery. Neurology 59(4): 514-523.

[39] Li Y, Chen J, Zhang C L, Wang L, Lu D, Katakowski M, Gao Q, Shen LH, Zhang J, Lu M, Chopp M. 2005. Gliosis and brain remodeling after treatment of stroke in rats with marrow stromal cells. Glia 49(3): 407-417. DOI: 10.1002/glia.20126.

[40] Kim D H, Yoo K H, Yim Y S, Choi J, Lee S H, Jung H L, Sung K W, Yang S E, Oh W I, Yang Y S, Kim $\mathrm{S} \mathrm{H}$, Choi S Y, Koo H H. 2006. Cotransplanted bone marrow derived mesenchymal stem cells (MSC) enhanced engraftment of hematopoietic stem cells in a MSC-dose dependent manner in NOD/SCID mice. Journal of Korean medical science 21(6): 1000-1004. DOI: 10.3346/jkms.2006.21.6.1000.

[41] Shen L H, Li Y, Chen J, Zhang J, Vanguri P, Borneman J, Chopp M. 2006. Intracarotid transplantation of bone marrow stromal cells increases axon-myelin remodeling after stroke. Neuroscience 137(2): 393399. DOI: 10.1016/j.neuroscience.2005.08.092.

[42] Potapova I A, Brink P R, Cohen I S, Doronin SV. 2008. Culturing of human mesenchymal stem cells as three-dimensional aggregates induces functional expression of CXCR4 that regulates adhesion to endothelial cells. Journal of Biological Chemistry 283(19): 13100-13107. DOI: 10.1074/jbc.M800184200.

[43] Mackensen A, Dräger R, Schlesier M, Mertelsmann R, Lindemann A. 2000. Presence of IgE antibodies to bovine serum albumin in a patient developing anaphylaxis after vaccination with human peptide-pulsed dendritic cells. Cancer Immunology, Immunotherapy 49(3): 152-156.

[44] Sundin M, Ringdén O, Sundberg B, Nava S, Götherström C, Le Blanc K. 2007. No alloantibodies against mesenchymal stromal cells, but presence of anti-fetal calf serum antibodies, after transplantation in allogeneic hematopoietic stem cell recipients. Haematologica 92(9): 1208-1215.

[45] Robinson N J, Picken A, Coopman K. 2014. Low temperature cell pausing: an alternative short-term preservation method for use in cell therapies including stem cell applications. Biotechnology letters 36(2): 201-209. DOI: 10.1007/s10529-013-1349-5.

[46] Kilkson H, Holme S, Murphy S. 1984. Platelet metabolism during storage of platelet concentrates at 22 degrees C. Blood 64(2): 406-414.

[47] Garvican E R, Cree S, Bull L, Smith R K, Dudhia J. 2014. Viability of equine mesenchymal stem cells during transport and implantation. Stem cell research \& therapy 5(4): 1. DOI: 10.1186/scrt483.

[48] Godwin E E, Young N J, Dudhia J, Beamish IC, Smith RK. 2012. Implantation of bone marrow - derived mesenchymal stem cells demonstrates improved outcome in horses with overstrain injury of the superficial digital flexor tendon. Equine Veterinary Journal 44(1): 25-32. DOI: 10.1111/j.20423306.2011.00363.x. 


\section{Table $\mathbf{1}$ (on next page)}

Real-time PCR primer sequences. 
1 Table 1. Real-time PCR primer sequences

Gene $\quad$ Forward primer $\quad$ Reverse primer

IDO1 CTGGGCATCCAGCAGACT TGAGCTGGTGGCATATATCTTCT

GAPDH AACAGCGACACCCACTCCTC CATACCAGGAAATGAGCTTGACAA

2 


\section{Figure 1}

Optimization of preservation media.

(A) Photos of cells on counting chamber and analysis of viability and cluster rate. White arrow indicated cell cluster. (B) Apoptosis analysis by flow cytometry . (C) Morphology of cells replated on 100-mm dish after storage. (D) Photos and analysis of CFU . Results were presented as the means \pm standard deviation for $n=3, * P<0.05$. 

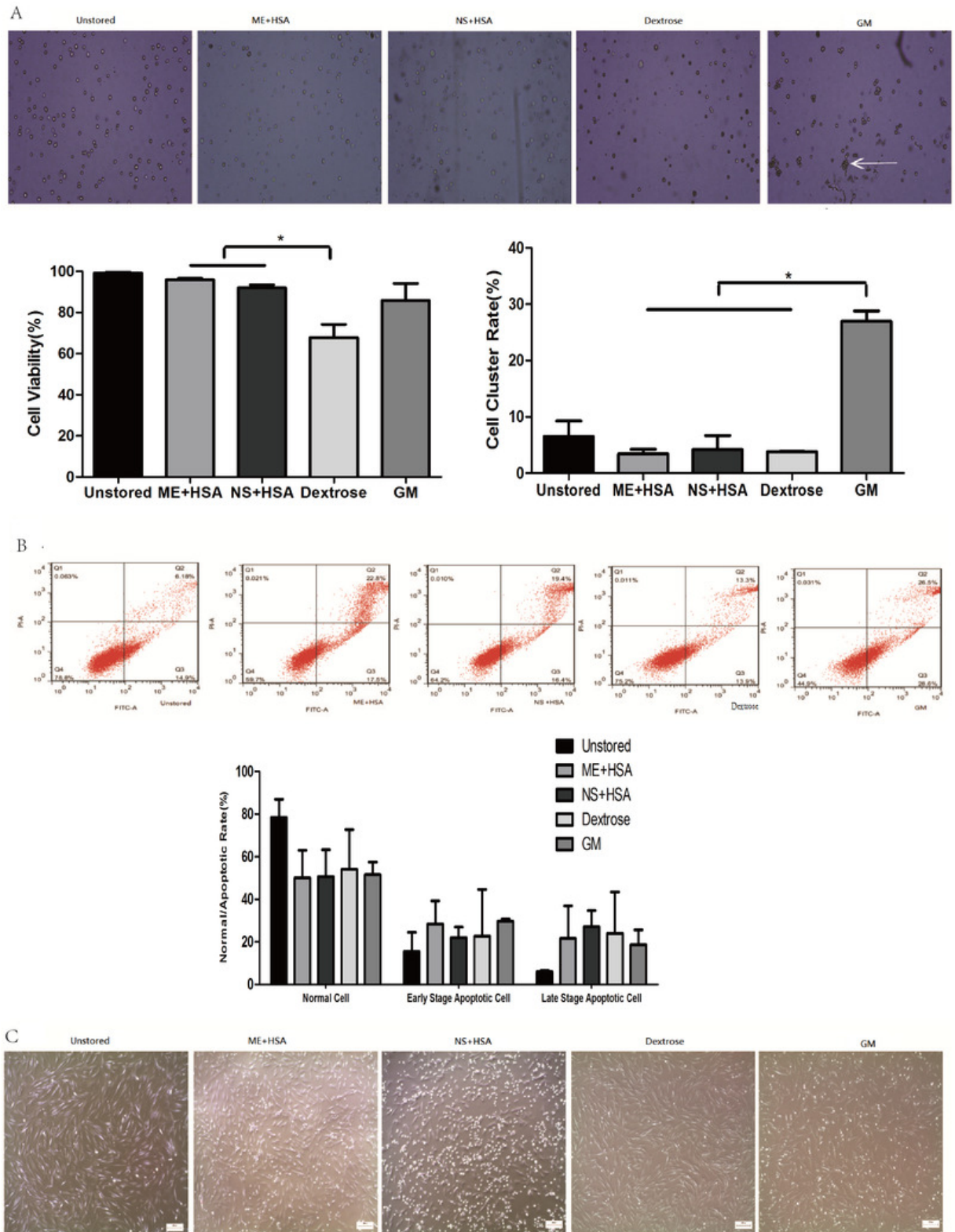

ME*HSA

NS+HSA
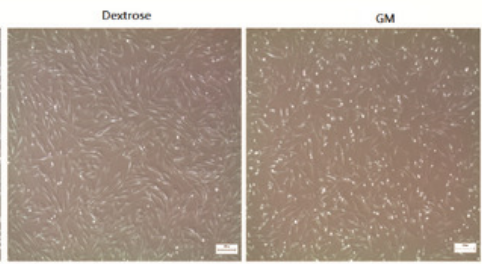

D
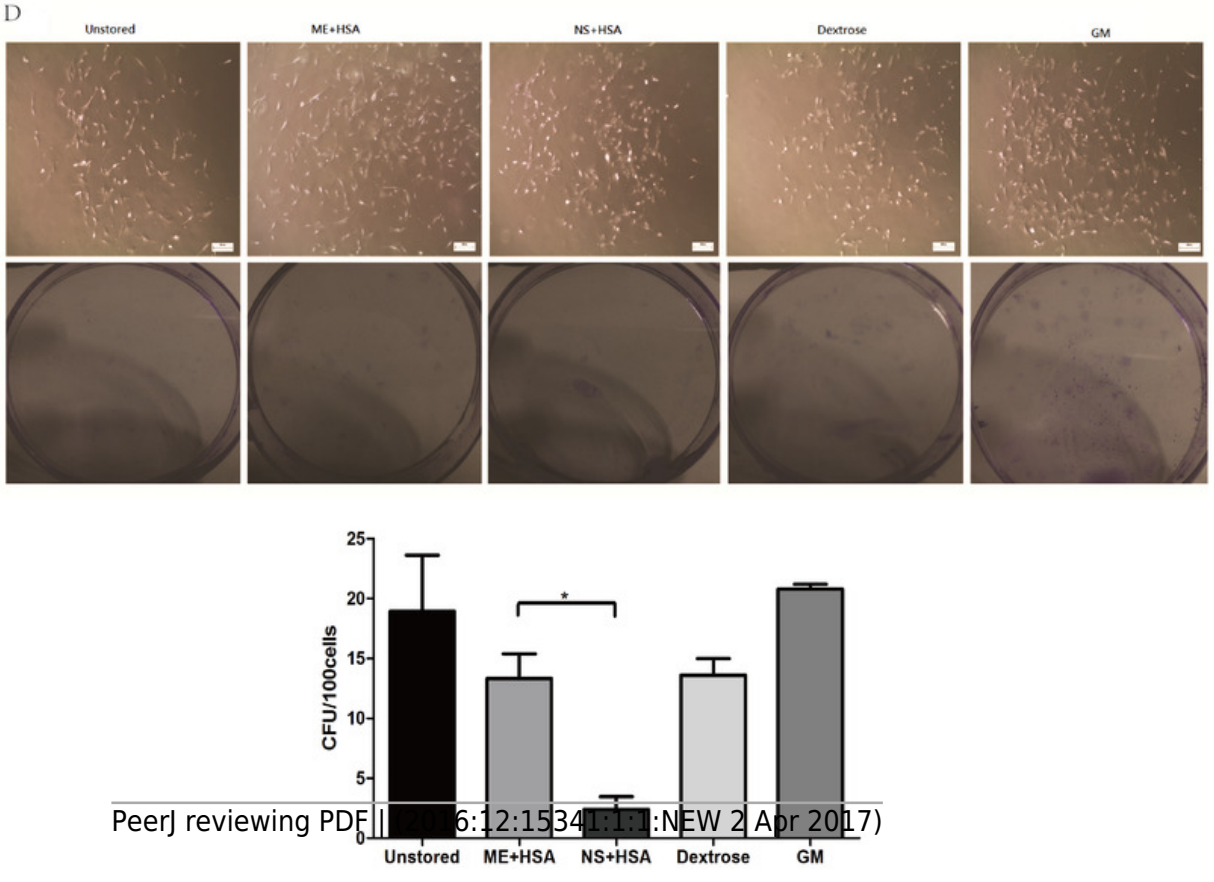
Figure 2

Optimization of durations.

(A) Apoptosis analysis of ADSCs in different durations by flow cytometry. (B) Morphology of cells re-plated on 100-mm dish. (C) CFU of cells in different durations. Results were presented as the means \pm standard deviation for $n=3, * P<0.05$.
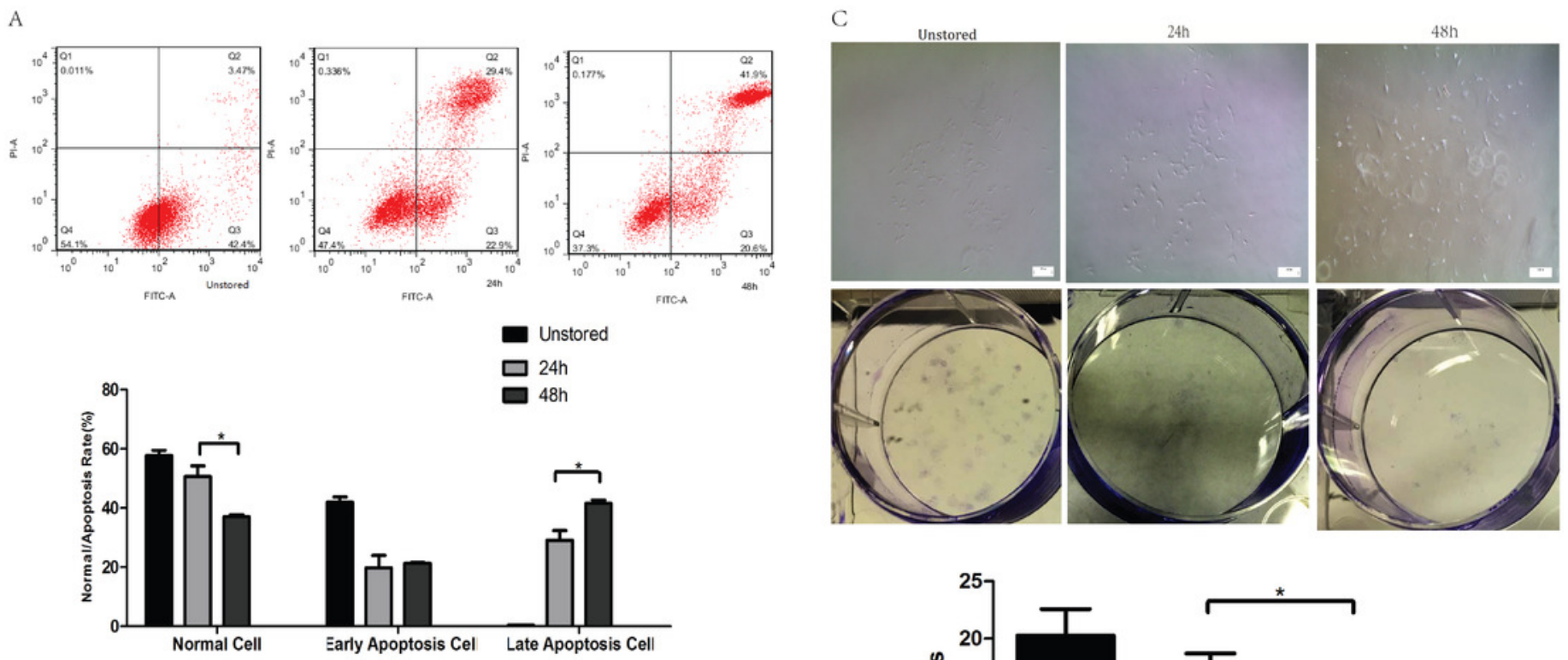

B

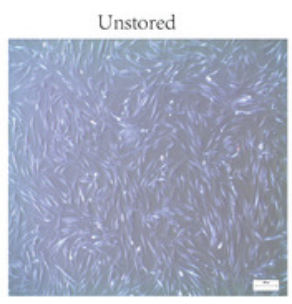

$24 \mathrm{~h}$

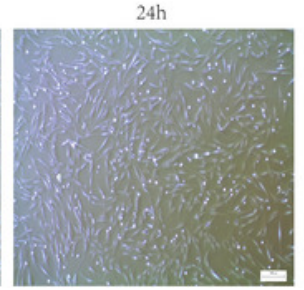

$48 \mathrm{~h}$

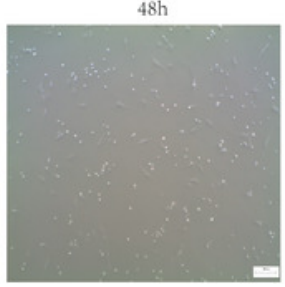

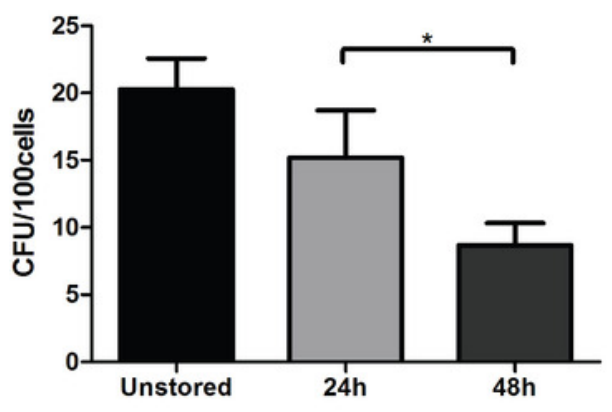


Figure 3

Optimization of cell concentrations.

(A)Apoptosis analysis of ADSCs by flow cytometry. (B) Morphology of cells re-plated on 100$\mathrm{mm}$ dish. (C)CFU of cells at different concentrations. Results were presented as the means \pm standard deviation for $\mathrm{n}=3, * \mathrm{P}<0.05$.
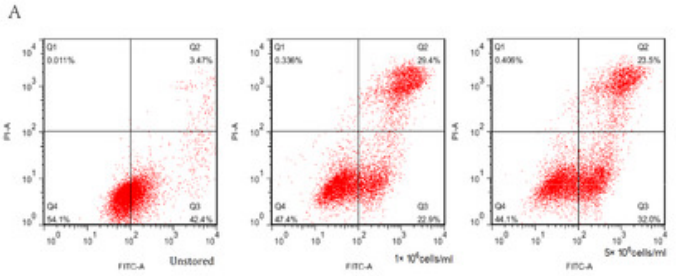

Unstored
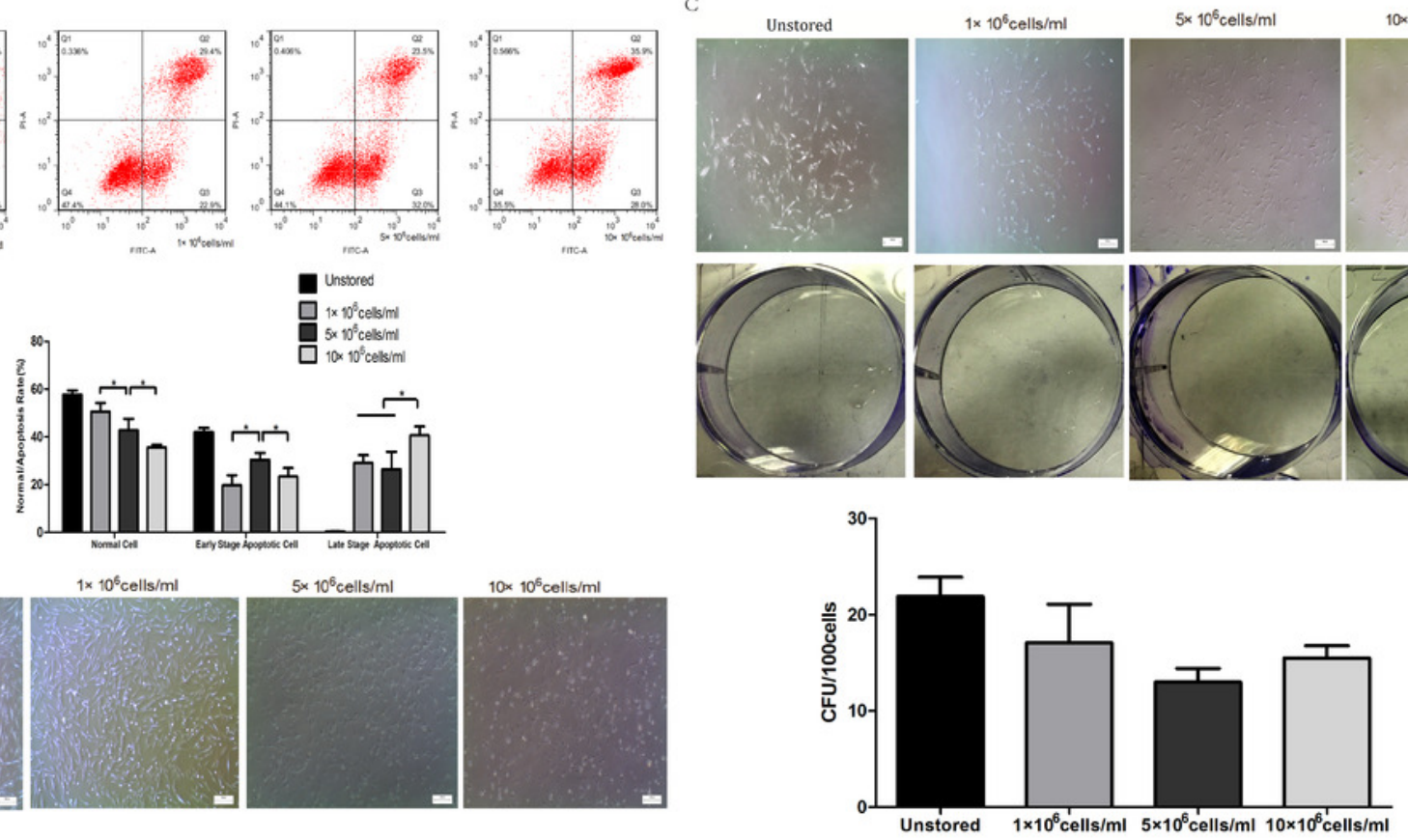
Figure 4

Proliferation of ADSCs at different cell concentrations.

Results were presented as the means \pm standard deviation for $n=3, * P<0.05$.

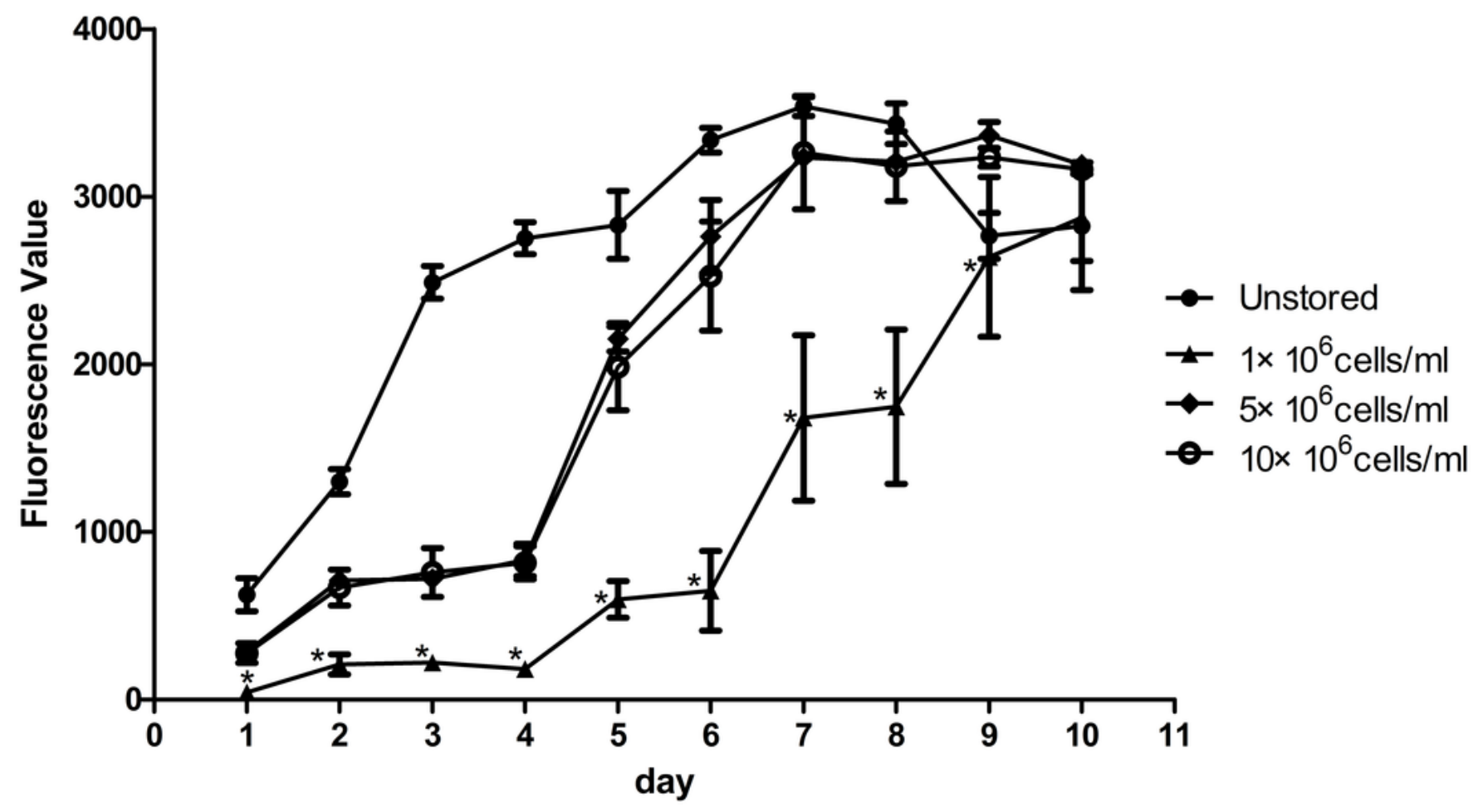


Figure 5

Multidifferentiation of ADSCs at different cell concentrations (A) Osteogenic differentiation. (B) Adipogenic differentiation.

Results were presented as the means \pm standard deviation for $n=3, * P<0.05$. 
A

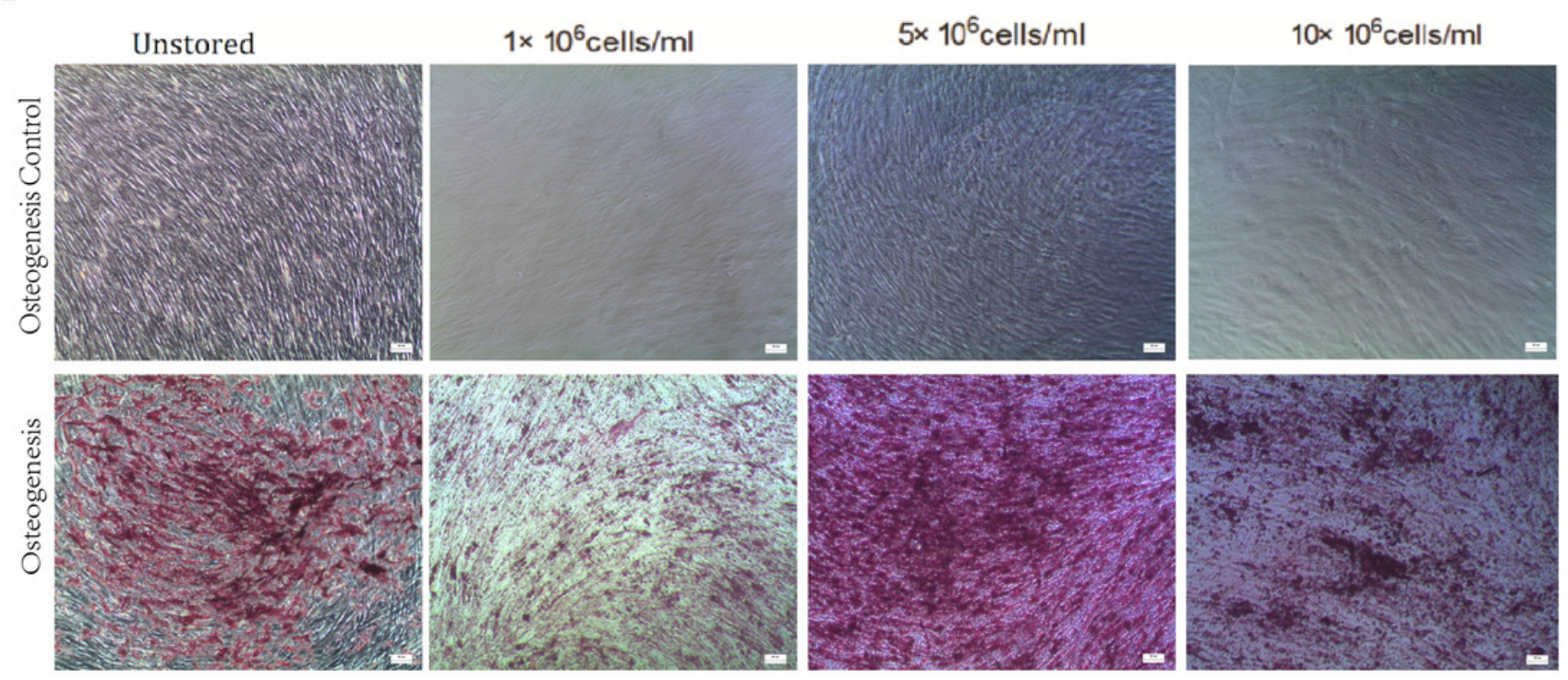

B
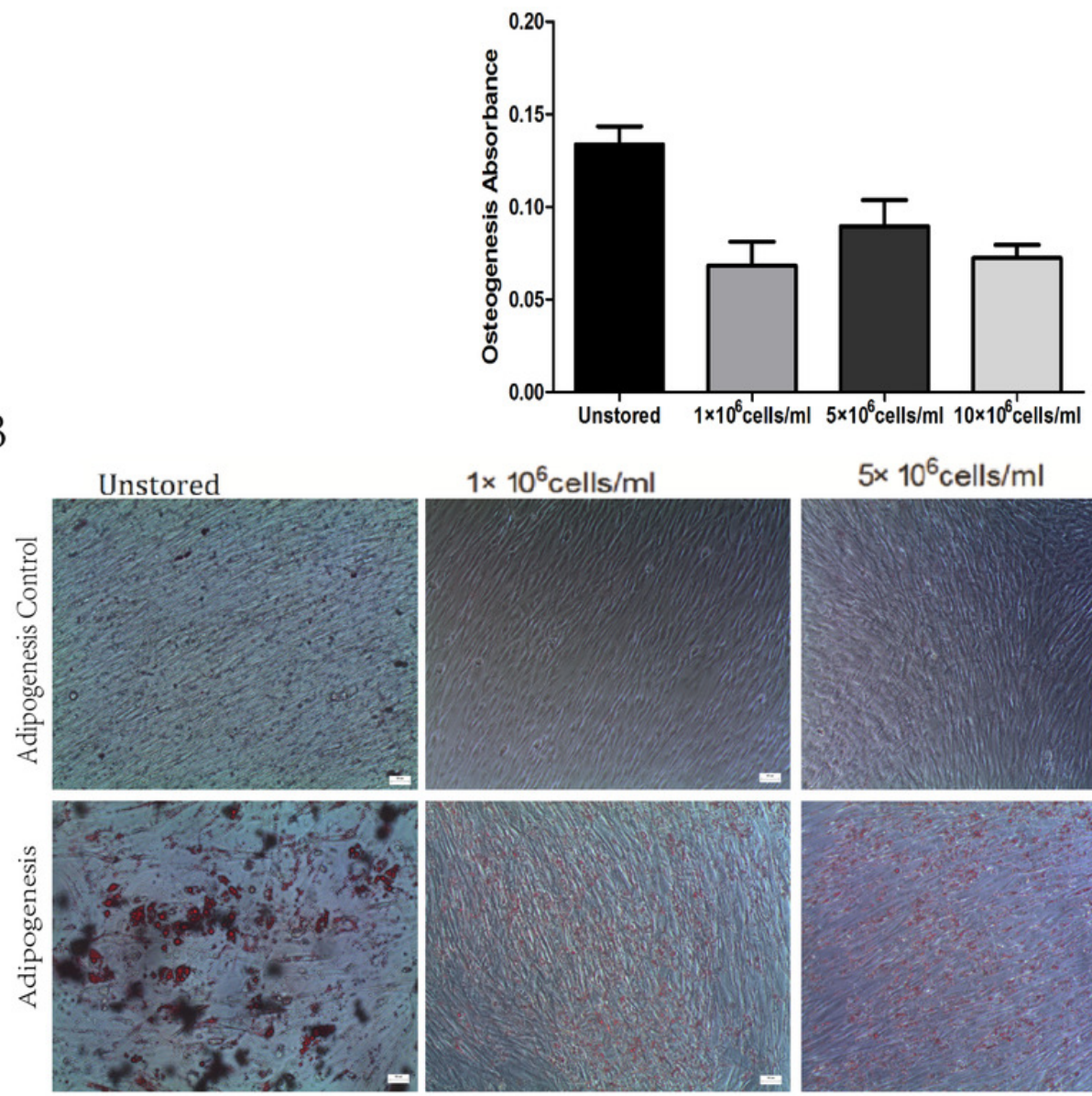

$1 \times 10^{6} \mathrm{cells} / \mathrm{ml}$

$5 \times 10^{6} \mathrm{cells} / \mathrm{ml}$

$10 \times 10^{6} \mathrm{cells} / \mathrm{ml}$
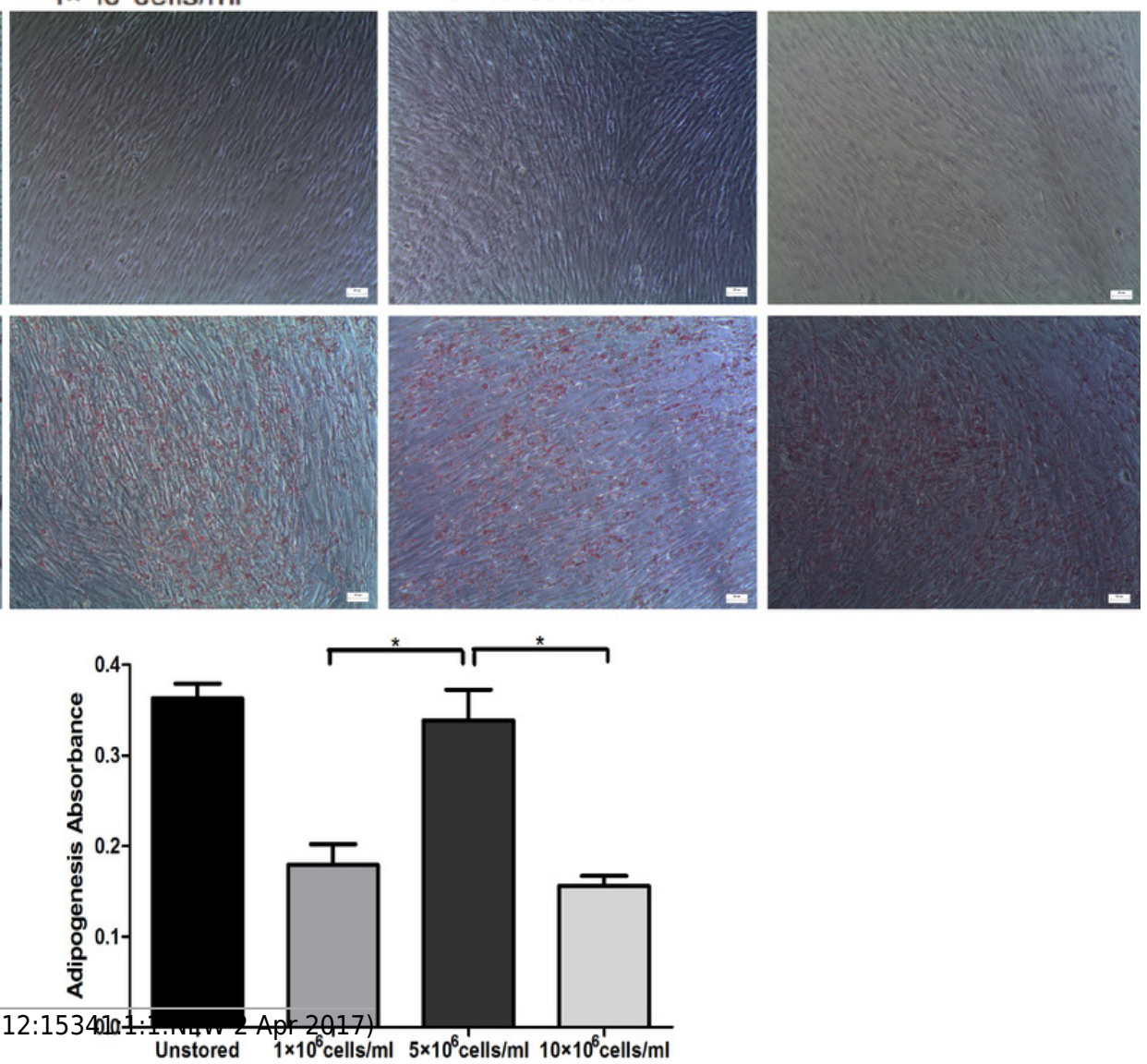
Figure 6

Evaluation of optimized solution.

(A) HLA-DR, CD34, CD45, CD73, CD90, CD105 expression. (B) Cell cycle distribution. (C)ID01 gene expression by RT-PCR. (D)Kyn concentration by HPLC. Results were presented as the means \pm standard deviation for $n=3$.

A
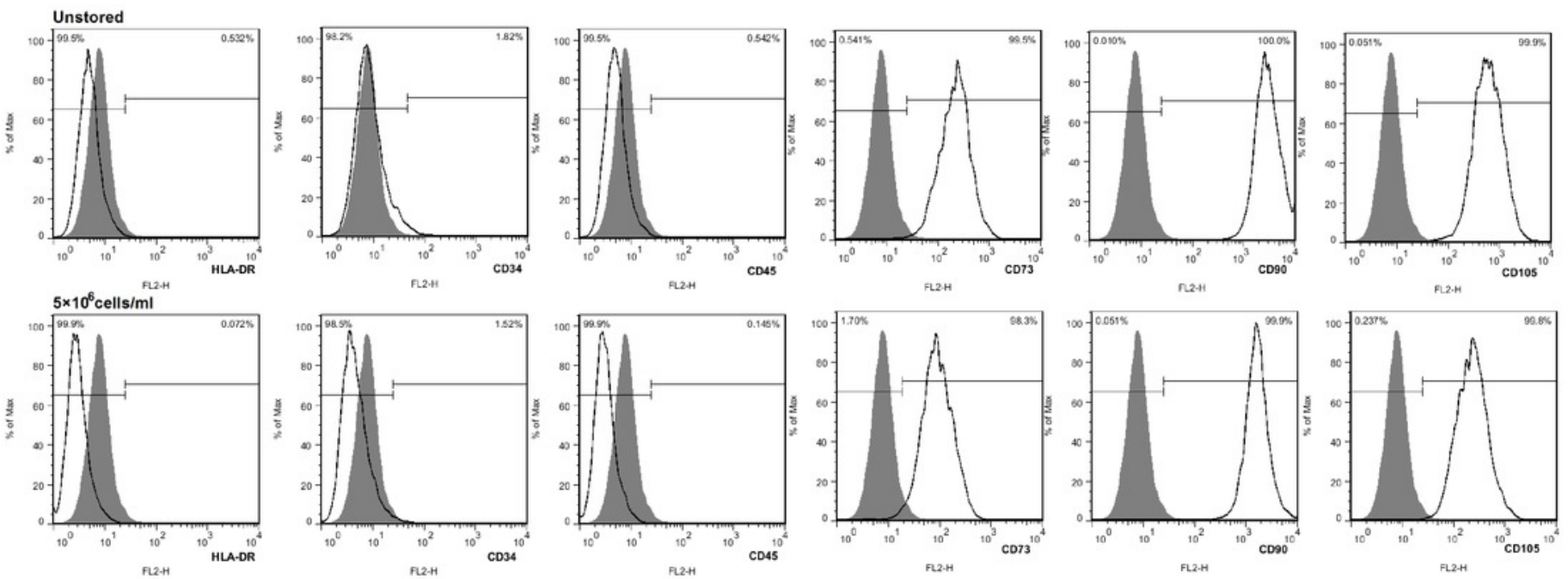

B

Unstored $\quad$ C

$\mathrm{D}$
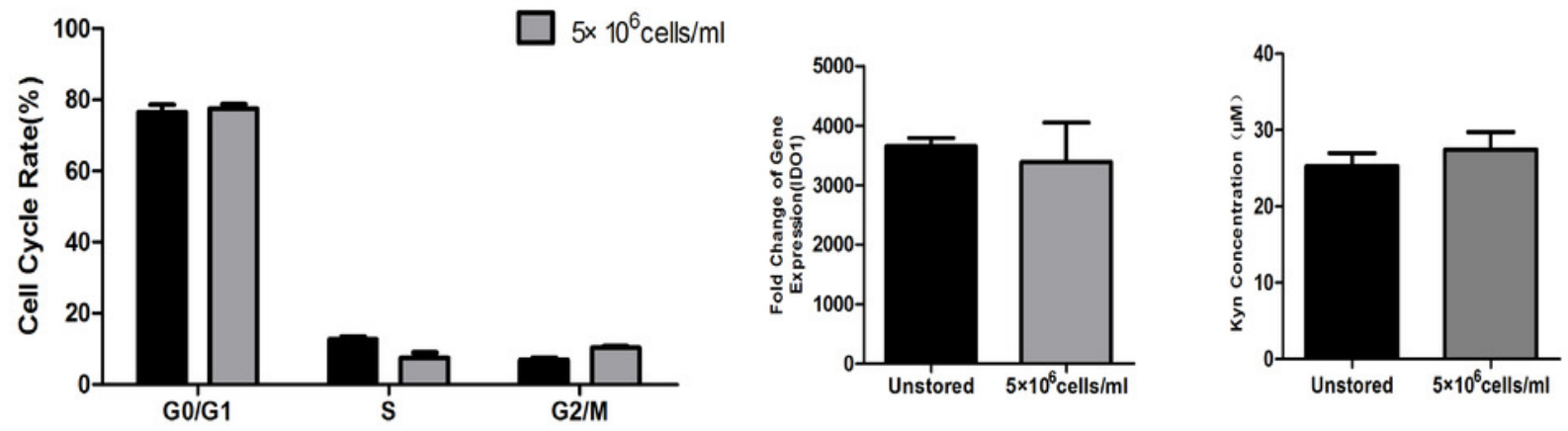